\title{
Bronchodilator test in extreme old age: Adverse effects of short-acting beta-2 adrenergic agonists with clinical repercussion and bronchodilator response
}

\author{
(D) Saulo Maia d'Avila Melo,2,3 \\ (iD) Larissa Alves de Oliveira ${ }^{4}$ \\ (D) Rodrigo dos Anjos Rocha \\ (D) José Lucas Farias Wanderley ${ }^{6}$
}

1. Doutor. Professor titular do Departamento de Medicina da Universidade Tiradentes, Aracaju, SE, Brasil 2. Mestre e doutor em Ciências da Saúde pela Universidade Federal de Sergipe, Aracaju, SE, Brasil 3. Preceptor da Residência de Clínica Medica do Hospital de Urgência de Sergipe, Aracaju, SE, Brasil; 4. Médica. Residência em Clínica Médica, Universidade Federal de Sergipe, Aracaju, SE, Brasil 5. Estudante da graduação em Medicina na Universidade Tiradentes, Aracaju, SE, Brasil 6. Médico residente em Anestesiologia. Hospital Universitário Professor Alberto Antunes - Universidade Federal de Alagoas. Maceió, AL, Brasil

\section{SUMMARY}

OBJECTIVE: To evaluate chronological age is a limiting factor to perform bronchodilator test, to determine significant adverse effects that may have clinical repercussions of short-acting beta 2 agonists and to assess the bronchodilator response in fourth age patients who submit the spirometry test.

METHODS: Cross-sectional and retrospective study. The sample extracted from the database (spirometer and respiratory questionnaire) of a pulmonary function service. Patients over 87 years were included in the research and were evaluated the bronchodilator response and significant adverse effects which may occasion clinical repercussion related to bronchodilator.

RESULTS: A sample of 75 patients aged $89.34 \pm 0,29$ years $(95 \% \mathrm{Cl}, 88,74-89,94)$, minimum age of 87 years and maximum of 97 years, predominance of female with 58,7\% (44/75). The bronchodilator test was performed in $86.6 \%$ (65/75) of the patients. The bronchodilator response was evaluated in 63 of the 65 patients (96.92\%) who underwent the bronchodilator test. The bronchodilator response was significant in $20.63 \%$ (13/63) of the patients. No clinical adverse effects were observed with bronchodilator medication (salbutamol) during or after exam.

CONCLUSIONS: Chronological age is not a limiting factor for the bronchodilator test, short-acting beta-2 agonists did not present adverse effects with significant clinical repercussion and were useful to help in diagnosis and therapeutic guidance in the fourth age group.

KEYWORDS: Bronchodilator agents; aged; aging; respiratory function tests; Spirometry; longevity

\section{INTRODUCTION}

The geriatric population has been increasing in Brasil and worldwide as a result of the decline in fertility and the significant increase in life expectan$\mathrm{cy}^{1-3}$. It is estimated that, by 2050 , the "fourth age" population ( $\geq 85$ years) will have more than tripled worldwide $^{1,2}$ and, in Brasil, the extremely elderly population ( $\geq 90$ years) will go from 394,000 in 2010 to around 3.5 million by $2050^{3}$. 
The prevalence of respiratory diseases and symptoms, such as cough and dyspnea, increases in the elderly population, so diagnostic investigation is required for the appropriate medical decision-making ${ }^{4,5}$.

Spirometry is the pulmonary function test most available and used in clinical practice to screen for respiratory diseases, and the bronchodilator test should be an integral part of the spirometry to aid in the diagnosis, treatment, and therapy follow-up of different respiratory pathologies ${ }^{6-9}$.

The chronological age is questioned as a limiting factor to properly perform spirometry ${ }^{10}$, and there is some insecurity from the lay population and even from health professionals regarding the use of short-acting beta-2 agonists on elderly people and/or with heart disease ${ }^{11,12}$, even in a single dose for an additional examination.

The goal of this study was to assess if the chronological age is a limiting factor for performing the bronchodilator test, determine the adverse effects with significant clinical significance of short-acting beta-2 agonists, and evaluate the bronchodilator response of spirometry in the fourth age.

\section{METHODS}

This is a retrospective study conducted at the University of Tiradentes (Unit), in the city of Aracaju (SE).

The sample was extracted from the database (spirometer and respiratory questionnaire) of a private laboratory of pulmonary function, from January 2012 to April 2017.

The research was approved by the Research Ethics Committee of Unit (CAAE: 67734717.2.0000.5371). There were no conflicts of interest.

The standardized respiratory questionnaire used in the spirometry assessed the anthropometric and demographic factors, respiratory symptoms, smoking, comorbidities, lung diseases and previous hear diseases, professional history, previous surgery and intubation, medications in use, clinical indication, and identification of the physician who requested the exam.

The study included patients $\geq 87$ years of chronological age and excluded those $\leq 86$ years.

In the first stage of the research, to assess the adverse effects of the inhaled bronchodilator, we considered only the first spirometry of each patient.

In the second stage, we evaluated the broncho- dilator response of the patients who underwent the bronchodilator test. Based on the diagnosis of the request for the spirometry test by the assistant physician and on the respiratory questionnaire, for purposes of statistical evaluation of the bronchodilator response, the patients were divided into two groups: obstructive respiratory disease and non-obstructive. Then, in order to assess the influence of chronological age on the bronchodilator response and significant adverse effects, patients were divided into two groups, one from 87 to 89 years old, and another $\geq 90$ years. Exams that did not meet the criteria for acceptability and reproducibility were excluded ${ }^{6}$.

Spirometry tests were performed in the same room, using the same spirometer with a pneumotachograph coupled to a computer (model Microlab-3500; Micro Medical Ltd., Kent, England), where the tests were saved, which allowed to retrieve individual exams stored by means of menu selection. Each exam was evaluated regarding flow-volume and volume-time curves, and the conventional spirometric variables, such as forced vital capacity (FVC), forced expiratory volume during the first second (FEV1), FEV1/FVC ratio, peak expiratory flow (PEF), and middle expiratory flows ${ }^{13}$.

The technical rules for examinations, criteria for acceptability, reproducibility, and interpretation of the spirometry test were determined according to the guidelines of the Brazilian Society of Pulmonology and Phthisiology ${ }^{6}$, and interpreted by the same pulmonologist, associated to the SBPT, and certified on spirometry.

The spirometry results were classified based on the lower limit of normality for the FEV1, FVC, and FEV1/FVC ratio. The bronchodilator test was considered with a significant variation when there were elevations of the FEV1 and/or FVC $\geq 200 \mathrm{ml}$ and $12 \%$, and variations in volume, flow, or both, in relation to its initial value ${ }^{14}$.

Soon after the completion of the initial spirometry, the bronchodilator test was performed by inhaling $100 \mathrm{mcg}$ sprays of salbutamol from a inhaler coupled with a spacer, repeated sequentially after an interval of 15 to 30 seconds, between maneuvers, four times, totaling $400 \mathrm{mcg}$ salbutamol. Then, the patient remained at rest for 15 to 20 minutes to repeat the spirometry after the use of the bronchodilator. The following were observed and considered adverse reactions with significant clinical repercus- 
sion from the use of salbutamol: induction of heart arrhythmia, coronary failure, heart failure, hypertensive crisis, cardiac arrest, and respiratory failure. The adverse effects were observed immediately after inhaling the bronchodilator drug during the waiting period to repeat the exam and after the exam was completed, when the patients were cleared to go home. Minor adverse effects, without clinical repercussions or increased risk to patients that justified a contraindication to the bronchodilator test, such tremors, reflex tachycardia, palpitations, flushing, and headache, were not taken into account.

The statistical analysis was performed using the Statistical Package for Social Sciences, version 21.0 (SPSS Inc., Chicago, IL, USA). Continuous variables were described as mean and standard deviation, and categorical variables were summarized by means of simple and relative frequencies. The chi-square test was used to assess the differences in bronchodilator response between the groups of patients. The significance level adopted was $\mathrm{p}<0.05$.

TABLE 1. DEMOGRAPHIC, ANTHROPOMETRIC, SMOKING ACTIVITY, AND COMORBIDITIES CHARACTERISTICS OF ELDERLY INDIVIDUALS $\geq 87$ YEARS

\begin{tabular}{|c|c|c|}
\hline Variables & $\geq 87$ years & $\mathrm{Cl} 95 \%$ \\
\hline Female, $\mathrm{n}(\%)^{1}$ & $44(58.7 \%)$ & \\
\hline $\mathrm{Age}^{2}$, years & $89.34 \pm 0.29$ year & $88.74-89.94$ \\
\hline Height, meters ${ }^{2}$ & $1.52 \pm 0.01$ & $1.50-1.55$ \\
\hline $\mathrm{BMI}^{2}$ & $27.02 \pm 0.58$ & $25.86-28.18$ \\
\hline Weight, $\mathrm{Kg}^{2}$ & $63.30 \pm 1.52$ & $60.26-66.35$ \\
\hline Nonsmokers1 & $46(61.3 \%)$ & \\
\hline Former smokers $^{1}$ & $26(34.7 \%)$ & \\
\hline Smokers1 & $3(4 \%)$ & \\
\hline \multicolumn{3}{|l|}{ Comorbidities, n (\%)1 } \\
\hline Asthma & $20(26.7 \%)$ & \\
\hline COPD & $22(29.3 \%)$ & \\
\hline Allergic rhinitis & $23(30.7 \%)$ & \\
\hline $\mathrm{SAH}$ & $33(44 \%)$ & \\
\hline Dyslipidemia & $17(22.7 \%)$ & \\
\hline OSA & $16(21.3 \%)$ & \\
\hline Diabetes mellitus & $14(18.7 \%)$ & \\
\hline Cerebrovascular & $6(8 \%)$ & \\
\hline Cognitive deficit & $7(9.3 \%)$ & \\
\hline GERD & $5(6.7 \%)$ & \\
\hline Prostatic Hyperplasia & $4(5.33 \%)$ & \\
\hline Arrhythmias & $4(5.33 \%)$ & \\
\hline Other comorbidities & $16(21.33 \%)$ & \\
\hline \multicolumn{3}{|c|}{$\begin{array}{l}\text { 1. Values as n (\%). } 2 \text { Values as mean } \pm \text { SD. Cl 95\%: Confidence interval; BMI } \\
\text { Body Mass Index, SAH: Systemic arterial hypertension; OSA: Obstructive sleep } \\
\text { apnea. Other comorbidities (depression, anxiety, coronary failure, previous breast } \\
\text { neoplasia, interstitial lung disease, pulmonary nodule, osteoarthritis, chronic cough, } \\
\text { hypothyroidism, auditory deficit). Some patients had one or more comorbidities. } \\
\text { Main Author: Saulo Maia d'Avila Melo }\end{array}$} \\
\hline
\end{tabular}

\section{RESULTS}

Among the 4,126 spirometric tests performed during the period evaluated, 77 (1.86\%) were of elderly individuals $\geq 87$ years. Two patients were excluded from this study for having repeated the exam. In total, we selected for this study 75 patients with a mean age of $89.34 \pm 0.29$ years (CI 95\% 88.74-89.94), minimum age of 87 years, and a maximum of 97 years, predominantly females $(58.7 \%, 44 / 75)$. There were $61.3 \%(46 / 75)$ non-smokers, 34.7\% (26/75) former smokers, and 4\% (3/75) active smokers. Table 1 shows the demographic, anthropometric, smoking activity, and comorbidities of the general sample.

The bronchodilator test was performed in $86.6 \%$ (65/75) of the patients; $13.3 \%$ (10/75) did not undergo the bronchodilator test. One patient $(1 / 75 ; 1.33 \%)$ refused to use the bronchodilator medication, and, in nine tests $(9 / 75 ; 12 \%)$, the assistant physician, when requesting the examination, excluded the bronchodilator test (Figure 1).

The assessment of significant response to the bronchodilator was performed in 63 of the 65 (96.92\%) patients who underwent the bronchodilator test; two examinations were excluded because they did not meet the criteria for acceptability and reproducibility and were, therefore, considered inconclusive tests (D Quality), making it impossible to interpret the bronchodilator test.

Among the 63 patients analyzed, 20.63\% (13/63) had a significant response to the bronchodilator; two patients $(2 / 63 ; 3.17 \%)$ responded to flow, three to volume $(4 / 63 ; 6.34 \%)$, and seven to flow and volume (7/63; 11.11\%). The bronchodilator response was not

FIGURE 1.: BRONCHODILATOR TEST AND ASSESSMENT OF SIGNIFICANT RESPONSE IN THE SAMPLE

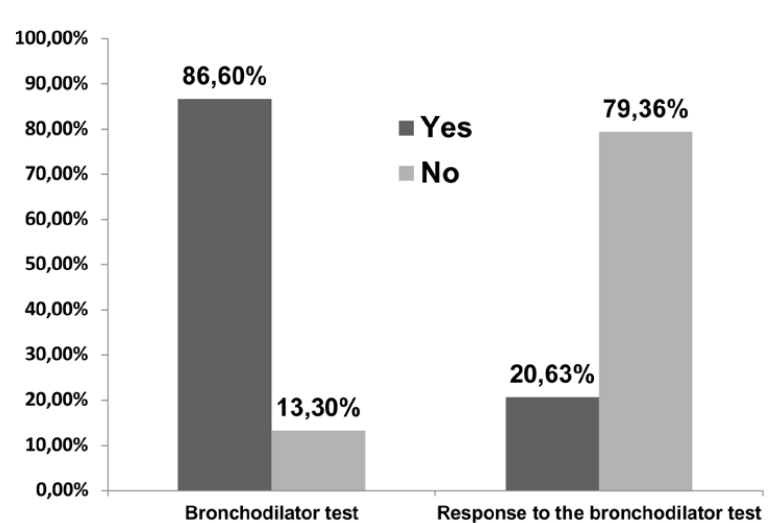

Footnote: ${ }^{1}$ Values as \%. The bronchodilator test was performed on 65 patients of the general sample (n: 75); and the assessment of the bronchodilator response was conducted in 63 of the 65 patient (due to exclusions). 
significant in $79.63 \%$ (50/63) of the patients who underwent the bronchodilator test.

After assessing the bronchodilator response per group, a positive response was found in both groups (obstructive: 9/34; 26.47\%; non-obstructive: 4/29; $13.79 \%$ ), with no significant difference between the groups ( $\mathrm{p}<0.11)$.

The chronological age did not influence the positive bronchodilator response in the groups per age group (87 to 89 years old: $10 / 44 ; 22.72 \%$; and $\geq 90$ years: $3 / 19 ; 15.78 \% ; p<0.23)$. No adverse effects were observed with a significant clinical repercussion of the bronchodilator medication during or after the test completion in all patients from both groups, so they were all discharged from the pulmonary function service a few minutes after the spirometry was completed.

\section{DISCUSSION}

Even with healthy aging, there is a reduction of the physiological capacity of all organs, in particular of the respiratory system. Elderly patients have an increased risk for respiratory diseases, since the frequent exposure to environmental toxins over a lifetime, particularly to tobacco smoke, environmental pollution, occupational dust, and respiratory infections, predispose to a higher risk of acute or chronic lung disease ${ }^{5}$.

Inhaled bronchodilator therapy is the basis for the treatment of obstructive respiratory diseases ${ }^{8.9}$. Spirometry with a bronchodilator test is commonly performed as a fundamental part of the evaluation of pulmonary function and has a preponderant role in the diagnosis, assessment of severity, and estimation of therapeutic response of respiratory diseases ${ }^{6-9,14-16}$.

There is currently a limited number of studies on spirometry in elderly patients and no discussion regarding the use of bronchodilators in the fourth age ${ }^{6.7}$.

In a recent publication that included more than 97,000 spirometric tests from five continents, in 33 countries, only $0.8 \%$ of individuals were more than 80 years old (chronological age), and of these, only 26 were $\geq 90$ years ${ }^{7}$.

We evidence here, in a pioneering way, the importance and the security of bronchodilators in the fourth age, with no adverse effects with significant clinical repercussions. A significant response to salbutamol was observed in $20.63 \%$ (13/63) of the patients in both groups (obstructive and non-obstructive), which demonstrates that there are no contraindications, so the repetition of the spirometry after bronchodilation should be routine, with safety, since it useful as a diagnostic aid and in therapeutic orientation, contributing to the clinical decision-making process in this elderly population.

In real life, the cardiovascular side effects of bronchodilators are one of the major concerns, and there is controversy regarding the relative systemic safety of the chronic use of fenoterol and salbutamol ${ }^{17-20}$. However, the safety of these medications in obstructive lung disease patients in acute crisis (asthma and COPD) is demonstrated in previous research $\mathrm{h}^{8,9,11,12}$.

The cardiovascular and systemic safety of high doses of inhaled fenoterol and salbutamol has been demonstrated in asthmatic patients in severe

TABLE 2. CONTRAINDICATIONS OF SPIROMETRY AND BRONCHODILATOR TEST ${ }^{15}$

\begin{tabular}{|c|c|}
\hline Absolute & Relative \\
\hline Hemodynamic instability. & Age under 5 to 6 years. \\
\hline $\begin{array}{l}\text { Pulmonary embolism. } \\
\text { Acute retinal detachment. }\end{array}$ & $\begin{array}{l}\text { Confused patient or with demen- } \\
\text { tia; uncooperative. }\end{array}$ \\
\hline $\begin{array}{l}\text { Recent pneumothorax }(\leq 2 \\
\text { weeks). }\end{array}$ & $\begin{array}{l}\text { Recent abdominal or thoracic } \\
\text { surgery. }\end{array}$ \\
\hline $\begin{array}{l}\text { Active respiratory infection: } \\
\text { viral, tuberculosis, others. }\end{array}$ & $\begin{array}{l}\text { Acute diarrhea or vomiting, nause- } \\
\text { ated state. }\end{array}$ \\
\hline Acute hemoptysis. & Hypertensive crisis. \\
\hline $\begin{array}{l}\text { Recent myocardial infarction. } \\
\text { Thoracic aortic aneurysm } \\
>6 \mathrm{~cm} \text {. }\end{array}$ & $\begin{array}{l}\text { Oral and maxillofacial disorders } \\
\text { that prevent oral coupling to the } \\
\text { device. }\end{array}$ \\
\hline $\begin{array}{l}\text { Unstable angina. } \\
\text { Unstable arrhythmia. }\end{array}$ & $\begin{array}{l}\text { Chest or abdominal pain that pre- } \\
\text { vents ventilatory maneuvers. }\end{array}$ \\
\hline Intracranial hypertension. & $\begin{array}{l}\text { Recent brain, eye, or otorhinolar- } \\
\text { yngologic surgery. }\end{array}$ \\
\hline \multicolumn{2}{|c|}{$\begin{array}{l}\text { Relative contraindications for the bronchodilator test } 15 \text { Known or likely adverse reac } \\
\text { tions to the intended bronchodilator. Known heart arrhythmia. Patient's fear regarding } \\
\text { the use of bronchodilators. } \\
\text { If there is a contraindication to spirometry, the bronchodilator test should not be per- } \\
\text { formed. The relative contraindications for the bronchodilator test should be assessed } \\
\text { individually with changes of the type of bronchodilator and analyzed on a case by case } \\
\text { basis, by evaluating the risk-benefit ratio. Table adapted }{ }^{15} \text {. }\end{array}$} \\
\hline
\end{tabular}

TABLE 3. GENERAL CONTRAINDICATIONS TO THE USE OF SELECTIVE SHORT-ACTING BETA-2 ADRENERGIC AGONIST AND IPRATROPIUM BROMIDE 21,22

Beta-2 adrenergic agonists
Hyperthyroidism. / Subvalvular aortic stenosis. / Hypertrophic
obstructive heart disease. / Tachyarrhythmias. / Sensitivity to
sympathomimetic drugs. / Hypersensitivity to any component of
the formulation.

\section{Ipratropium Bromide}

Hypersensitivity to any component of the formulation. / Hypersensitivity to atropine or its derivatives. / Use with caution in narrow-angle glaucoma, bladder obstruction, prostate hyperplasia, and myasthenia gravis.

Table adapted(21, 22) 
acute crisis $^{18}$. In COPD exacerbations, the use of short-acting beta-2 agonists, through inhaling did not increase the risk of fatal or nonfatal myocardial infarction ${ }^{11,19}$.

Spirometry is an outpatient elective examination in which bronchodilators are used in a single dose or in low doses when compared to those used during crises of acute or chronic lung disease patients. Our patients were not in an acute crisis; therefore, they had a lower probability of triggering cardiovascular complications.

Bronchodilators are safe drugs when used in the recommended doses ${ }^{8,9,11,12,20}$. In spirometry, it is recommended using a short-acting beta-2 (salbutamol) or a short-acting anticholinergic (ipratropium bromide), preferably in spray, because of its availability, ease of use, and $\operatorname{cost}^{6,14-16}$ : the dose of spray salbutamol, 400 $\mathrm{mcg}$ (4 jets of $100 \mathrm{mcg}$ ), preferably with a spacer, with a repetition of the examination after 15 minutes, and a dose of ipratropium bromide, of $160 \mathrm{mcg}$ ( 8 jets x 20 $\mathrm{mcg}$ ), with a repetition of the examination after 30 to 45 minutes $^{9,14-16}$. Ipratropium bromide presents a lower incidence of adverse effects, especially cardiovascular ones, in comparison to beta-2 agonists ${ }^{21}$.

With there is a contraindication to spirometry, the bronchodilator test, consequently, should not be performed (Table 2).

Research regarding contraindications specific to the bronchodilator test during spirometry is limited ${ }^{6,14-16}$. We did not find in the literature any absolute contraindication for the bronchodilator test, and important adverse effects (severe cardiac arrhythmia, hypertensive crisis, coronary failure, heart failure, or respiratory failure) triggered by the bronchodilator test.

The contraindications, in general, to bronchodilators used in the bronchodilator test (short-acting beta-2 agonists and ipratropium bromide) are shown in Table 3.

Reports of smaller risks without clinical repercussions, including tremors of the extremities, reflex tachycardia, excitation, flushing, palpitations, headache, and dizziness do not justify a contraindication to the bronchodilator test, since these cause only concern to patients (often due to lack of prior guidance) and health professionals who are not used to the medication. However, spirometry requests that specify the non-use of the bronchodilator test are justified, particularly in elderly patients or with heart disease.

Therefore, when there is no contraindication to spirometry, the bronchodilator test should be performed respecting its contraindications, which should be analyzed on a case by case basis by evaluating the risk-benefit ratio (Tables 2 and 3).

The use of a specific questionnaire to assess adverse effects without significant clinical repercussions, the potassium dose, and the lack of cardiovascular monitoring during and after the completion of the bronchodilator test were limitations of our study because of its retrospective design.

\section{CONCLUSION}

Our study demonstrated that chronological age is not a limiting factor for bronchodilator tests, that short-acting selective adrenergic beta- 2 agonists presented no adverse effects with significant clinical consequences, and that they were useful to assist in the diagnosis and therapeutic orientation of patients in the fourth age.

\section{Contribution of the authors}

SMAM - Concept, creation, and formatting of the research, literature review, submission to the Research Ethics Committee, database review, discussion of the results and statistics, discussion with the literature, and drafting of the article.

LAO; RAR; JLFW - Literature review, drafting, and review of the database, discussion of the results and statistics, discussion with the literature, and drafting of the article.

\section{RESUMO}

OBJETIVOS: Avaliar se idade cronológica é um fator limitante para realizar prova broncodilatadora, determinar efeitos adversos com repercussão clínica significativa dos Beta 2 agonistas de curta ação e avaliar a resposta broncodilatadora na espirometria, na quarta idade.

MÉTODOs: Estudo transversal, retrospectivo. Amostra extraída do banco de dados (espirometro e questionário respiratório) de um serviço de função pulmonar. Incluídos na pesquisa pacientes com $\geq 87$ anos sendo avaliado a resposta broncodilatadora e efeitos adversos com repercussão clínica significativa ao broncodilatador.

RESULTADOS: Amostra de 75 pacientes com idade de 89,34 0 0,29 anos (IC 95\% 88,74 - 89,94), idade mínima de 87 anos e máxima de 97 anos, predominando o sexo feminino com 58,7\% (44 / 75). A prova broncodilatadora foi realizada em 86,6 \% (65 / 75) dos pacientes. 
A avaliação da resposta ao broncodilatador foi feita em 63 dos 65 pacientes (96,92\%) que realizaram a prova broncodilatadora. A resposta broncodilatadora foi significativa em 20,63 \% (13 / 63) dos pacientes. Não foi observado efeito adversos com repercussão clínica significativa da medicação broncodilatadora (salbutamol) durante ou após sua realização.

CONCLUSÕES: A idade cronológica não é um fator limitante para realização da prova broncodilatadora, os agonistas beta-2 de curta ação não apresentaram efeitos adversos com repercussão clinica significativa e foram úteis para auxiliar no diagnóstico e orientação terapêutica, na quarta idade.

PALAVRAS-CHAVE: Broncodilatadores; Idoso; Envelhecimento; Testes de função respiratória; Espirometria

\section{REFERENCES}

1. World Health Organization. Active ageing: a policy framework. April 2002. [cited 2019 Jun 17]. Available from: http://www.who.int/ageing/ publications/active_ageing/en/

2. Davidson S, Goodwin J, Rossall P. Improving later life. Understanding the oldest old. [cited 2019 jul 17]. Available from: https://www.ageuk.org.uk/ globalassets/age-uk/documents/reports-and-publications/reports-andbriefings/health--wellbeing/rb_feb13_understanding_the_oldest_old_ improving_later_life.pdf

3. Instituto Brasileiro de Geografia e Estatística. Projeção da população do Brasil por sexo e idade: 2000-2060. [cited 2017 Mar 22]. Available from: http://www.ibge.gov.br/home/estatistica/populacao/projecao_da_populacao/2013/default_tab.shtm

4. Pezzoli L, Giardini G, Consonni S, Dallera I, Bilotta C, Ferrario G, et al. Quality of spirometric performance in older people. Age Ageing. 2003;32(1):43-6.

5. Vaz Fragoso CA, Gill TM. Respiratory impairment and the aging lung: a nove paradigm for assessing pulmonary function. | Gerontol A Biol Sci Med Sci. 2012;67(3):264-75

6. Sociedade Brasileira de Pneumologia e Tisiologia. Diretrizes para testes de função pulmonar. J Pneumol. 2002;28(Supl. 3):S1-S238.

7. Quanjer PH, Stanojevic S, Cole TJ, Baur X, Hall GL, Culver BH, et al; ERS Global Lung Function Initiative. Multi-ethnic reference values for spirometry for the 3-95-yr age range: the global lung function 2012 equations. Eur Respir J. 2012;40(6):1324-43.

8. Global Initiative for Asthma - Global Strategy for Asthma Management and Prevention, 2018. homepage on the Internet. [cited 2019 Fev 02]. Available from: https://ginasthma.org/wp-content/uploads/2018/04/wms-GINA2018-report-V1.3-002.pdf

9. Global Initiative for Chronic Obstructive Lung Disease [homepage on the Internet. Bethesda: GOLD. Global Strategy for the Diagnosis, Management and Prevention of COPD 2018. [cited 2019 Fev 03]. Available from: https:// goldcopd.org/wp-content/uploads/2018/11/GOLD-2019-v1.7-FINAL14Nov2018-WMS.pdf

10. Bellia V, Pistelli R, Catalano F, Antonelli-Incalzi R, Grassi V, Melillo G, et al. Quality control of spirometry in the elderly. The SA.R.A. study. SAlute Respiration nell'Anziano $=$ Respiratory Health in the Elderly. Am | Respir Crit Care Med. 2000;161(4 Pt 1):1094-100.
11. Imre N, Gregory AS. Management of the patient with COPD and cardiovascular disease. UpToDate, 2018. [cited 2018 Nov 30]. Available from: http:// www.uptodate.com/online

12. Gary TF, Barry M. Management of stable chronic obstructive pulmonar disease. UpToDate, 2018. [cited 2018 Nov 30]. Available from: http://www. uptodate.com/online

13. Crapo RO, Morris AH, Gardner RM. Reference spirometric values using techniques and equipment that meet ATS recommendations. Am Rev Respir Dis. 1981;123(6):659-64

14. Pellegrino R, Viegi G, Brusasco V, Crapo RO, Burgos F, Casaburi R, et al. Interpretative strategies for lung function tests. Eur Respir J. 2005;26(5):948-68.

15. García-Río F, Calle M, Burgos F, Casan P, Del Campo F, Galdiz JB, et al. Spirometry. Spanish Society of Pulmonology and Thoracic Surgery (SEPAR). Arch Bronconeumol. 2013;49(9):388-401.

16. Miller MR, Hankinson I, Brusasco V, Burgos F, Casaburi R, Coates A, et al; ATS/ERS Task Force. Standardization of spirometry. Eur Respir J. 2005;26(2):319-38.

17. Lipworth BJ, Newnham DM, Clark RA, Dhillon DP, Winter $J H, M c D e v i t t$ DG. Comparison of the relative airways and systemic potencies of inhaled fenoterol and salbutamol in asthmatic patients. Thorax. 1995;50(1):54-61.

18. Newhouse MT, Chapman KR, McCallum AL, Abboud RT, Bowie DM, Hodder RV, et al. Cardiovascular safety of high doses of inhaled fenoterol and albuterol in acute severe asthma. Chest. 1996;110(3):595-603.

19. Suissa $S$, Assimes T, Ernst P. Inhaled short acting beta agonist use in COPD and the risk of acute myocardial infarction. Thorax. 2003;58(1):43-6.

20. Lemanske RF, Bochner BS, Hollingsworth $H$. Beta agonists in asthma: controversy regarding chronic use. UpToDate, 2018. [cited 2018 Nov 30]. Available from: http://www.uptodate.com/online

21. Leitão Filho FSS. Especialidades farmacêuticas mais utilizadas em pneumologia. In: Pereira CAC, Holanda MA, eds. Medicina respiratória. São Paulo: Atheneu; 2014. p.1621-38.

22. Ferreira MAP. Principais medicamentos prescritos em consultório. In: Menna Barreto SS, ed. Pneumologia no consultório. Porto Alegre: Artmed; 2009. p.735-64. 
Regarding the article "Bronchodilator test in extreme old age: Adverse effects of short-acting beta2 adrenergic agonists with clinical repercussion and bronchodilator response" with DOI number: http:// dx.doi.org/10.1590/1806-9282.65.11.1343, published in Journal of the Brazilian Medical Association, 2019;65(11), page 1343, figure 1 and summary (in portuguese and english) changed from:

\section{SUMMARY}

OBJECTIVE: To evaluate chronological age as a limiting factor to perform the bronchodilator test, determine significant adverse effects of short-acting beta 2 agonists with clinical repercussions, and assess bronchodilator response in extreme-old-age patients who undergo the spirometry test. METHODS: This is a cross-sectional and retrospective study. The sample was extracted from the database (spirometer and respiratory questionnaire) of a pulmonary function service. Patients over 90 years old were included in the research, and we evaluated their bronchodilator response and its significant adverse effects that may have clinical repercussions related to the bronchodilator. RESULTS: A sample of 25 patients aged $92.12 \pm$ 2.22 years $(95 \% \mathrm{Cl}, 91.20$ - 93.04), with a minimum age of 90 years and a maximum of 97 years and a predominance of females with $72 \%$ (18/25). The bronchodilator test was performed in $84 \%(21 / 25)$ of the patients. The bronchodilator response was evaluated in 19 of the 21 patients (90.47\%) who underwent the bronchodilator test. Two tests did not meet the criteria of acceptability and reproducibility. No clinical adverse effects were observed with the bronchodilator medication (salbutamol) during or after the exam.

CONCLUSIONS: Chronological age is not a limiting factor for the bronchodilator test, short-acting beta-2 agonists did not present adverse effects with significant clinical repercussion and were useful in the diagnosis and therapeutic guidance of extreme-old-age patients.

KEYWORDS: Bronchodilator agents; aged; aging; respiratory function tests; Spirometry; longevity

\section{RESUMO}

OBJETIVOS: Avaliar se idade cronológica é um fator limitante para realizar prova broncodilatadora, determinar efeitos adversos significativos com repercussão clínica dos beta-2 agonistas de curta ação e avaliar a resposta broncodilatadora na espirometria, na velhice extrema.

MÉTODOS: Estudo transversal, retrospectivo. Amostra extraída do banco de dados (espirômetro e questionário respiratório) de um serviço de função pulmonar. Incluídos na pesquisa pacientes com $\geq 90$ anos, sendo avaliados a resposta broncodilatadora e efeitos adversos significativos com repercussão clínica ao broncodilatador. RESULTADOS: Amostra de 25 pacientes com idade de 92,12 \pm 2,22 anos (IC 95\%; 91,20 - 93,04), idade mínima de 90 anos e máxima de 97 anos, predominando o sexo feminino, com $72 \%$ (18/25). A prova broncodilatadora foi realizada em 84\% (21/25) dos pacientes. A avaliação da resposta ao broncodilatador foi feita em 19 dos 21 pacientes (90,47\%) que realizaram a prova broncodilatadora, uma vez que dois desses exames não preencheram os critérios de aceitabilidade e reprodutibilidade. A resposta broncodilatadora foi significativa em 10,52\% (2/19) dos pacientes, ambos portadores de pneumopatia obstrutiva. Não foram observados efeitos adversos com repercussão clínica da medicação broncodilatadora (salbutamol) durante ou após sua realização. CONCLUSÕES: A idade cronológica não é um fator limitante para a realização da prova broncodilatadora, os beta-2 agonistas de curta ação não apresentaram efeitos adversos com repercussão clínica significativa e foram bastante úteis para auxiliar no diagnóstico e orientação terapêutica na velhice extrema.

PALAVRAS-CHAVE: Broncodilatadores; Idoso; Envelhecimento; Testes de função respiratória; Espirometria;

\section{FIGURE 1 (BLANK)}

TO 
SUMMARY

OBJECTIVE: To evaluate chronological age is a limiting factor to perform bronchodilator test, to determine significant adverse effects that may have clinical repercussions of short-acting beta 2 agonists and to assess the bronchodilator response in fourth age patients who submit the spirometry test.

METHODS: Cross-sectional and retrospective study. The sample extracted from the database (spirometer and respiratory questionnaire) of a pulmonary function service. Patients over 87 years were included in the research and were evaluated the bronchodilator response and significant adverse effects which may occasion clinical repercussion related to bronchodilator.

RESULTS: A sample of 75 patients aged $89.34 \pm$ 0,29 years $(95 \% \mathrm{Cl}, 88,74-89,94)$, minimum age of 87 years and maximum of 97 years, predominance of female with 58,7\% (44/75). The bronchodilator test was performed in $86.6 \%$ (65/75) of the patients. The bronchodilator response was evaluated in 63 of the 65 patients (96.92\%) who underwent the bronchodilator test. The bronchodilator response was significant in $20.63 \%$ (13/63) of the patients. No clinical adverse effects were observed with bronchodilator medication (salbutamol) during or after exam.

CONCLUSIONS: Chronological age is not a limiting factor for the bronchodilator test, short-acting beta-2 agonists did not present adverse effects with significant clinical repercussion and were useful to help in diagnosis and therapeutic guidance in the fourth age group.

KEYWORDS: Bronchodilator agents; aged; aging; respiratory function tests; Spirometry; longevity

\section{RESUMO}

OBJETIVOS: Avaliar se idade cronológica é um fator limitante para realizar prova broncodilatadora, determinar efeitos adversos com repercussão clínica significativa dos Beta 2 agonistas de curta ação e avaliar a resposta broncodilatadora na espirometria, na quarta idade.

MÉTODOS: Estudo transversal, retrospectivo. Amostra extraída do banco de dados (espirometro e questionário respiratório) de um serviço de função pulmonar. Incluídos na pesquisa pacientes com $\geq 87$ anos sendo avaliado a resposta broncodilatadora e efeitos adversos com repercussão clínica significativa ao broncodilatador.

RESULTADOS: Amostra de 75 pacientes com idade de 89,34 \pm 0,29 anos (IC 95\% 88,74 - 89,94), idade mínima de 87 anos e máxima de 97 anos, predominando o sexo feminino com 58,7 \% (44 / 75). A prova broncodilatadora foi realizada em 86,6 $\%$ (65 / 75) dos pacientes. A avaliação da resposta ao broncodilatador foi feita em 63 dos 65 pacientes (96,92\%) que realizaram a prova broncodilatadora. A resposta broncodilatadora foi significativa em 20,63 \% (13 / 63) dos pacientes. Não foi observado efeito adversos com repercussão clínica significativa da medicação broncodilatadora (salbutamol) durante ou após sua realização.

CONCLUSÕES: A idade cronológica não é um fator limitante para realização da prova broncodilatadora, os agonistas beta-2 de curta ação não apresentaram efeitos adversos com repercussão clinica significativa e foram úteis para auxiliar no diagnóstico e orientação terapêutica, na quarta idade.

PALAVRAS-CHAVE: Broncodilatadores; Idoso; Envelhecimento; Testes de função respiratória; Espirometria;

Figure 1:

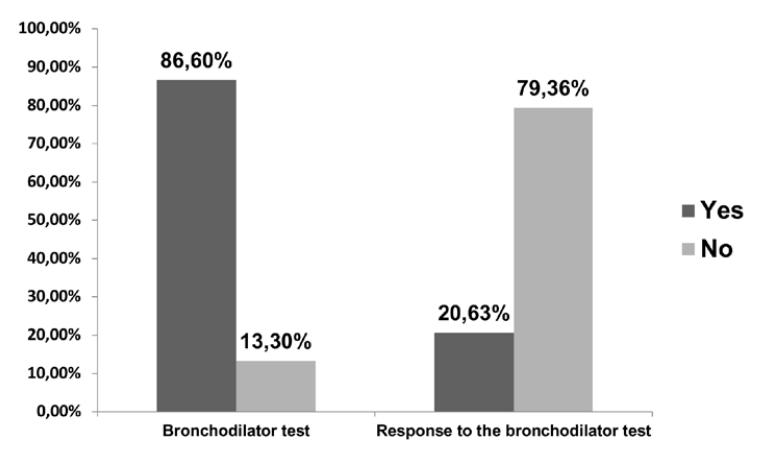

FIGURE 1.: BRONCHODILATOR TEST AND ASSESSMENT OF SIGNIFICANT RESPONSE IN THE SAMPLE

Footnote: ${ }^{1}$ Values as \%. The bronchodilator test was performed on 65 patients of the general sample ( $n: 75)$; and the assessment of the bronchodilator response was conducted in 63 of the 65 patient (due to exclusions). 